\title{
Impact of protective haemoglobins $C$ and $S$ on $P$. falciparum malaria transmission in endemic area
}

\author{
Louis C Gouagna ${ }^{1,2^{*}}$, Germana Bancone ${ }^{3}$, Frank $\mathrm{Yao}^{4}$, Carlo Costantini ${ }^{5}$, Jean-Bosco Ouedraogo ${ }^{4}$, David Modiano ${ }^{3}$ \\ From Parasite to Prevention: Advances in the understanding of malaria \\ Edinburgh, UK. 20-22 October 2010
}

Human genetic factors play a key role in determining the resistance/ susceptibility to infectious diseases. It is unknown whether genetic makeup may also influence host efficiency to transmit pathogens. With regard to malaria, a major selective force in recent human evolution, protective erythrocyte variants have been describe, but little is known as to their possible impact on the transmission of the parasite from the human host to the Anopheles vector.

Here, we performed genetic, parasitological and entomological investigations involving a total of 3799 human subjects carrying the $\mathrm{HbAA}, \mathrm{HbAS}, \mathrm{HbAC}$ and $\mathrm{HbCC}$ $\beta$-globin genotypes in order to determine whether variation in host infectivity to the Anopheles vector can be accounted for by host genetic variation. Although no differences were observed in asexual parasite rates and densities among $\beta$-globin genotypes, the $\mathrm{HbCC}$ genotype was characterized by higher gametocyte rates than the rest of the studied population.

Furthermore, serial infection experiments with blood from $\mathrm{CC}, \mathrm{AC}, \mathrm{AS}$, and AA donors showed that the protective haemoglobins $\mathrm{C}\left(\mathrm{HbC}, \beta 6 \mathrm{Glu}^{\circ} \mathrm{Lys}\right)$ and $\mathrm{S}$ $\left(\beta 6 \mathrm{Glu}^{\circ} \mathrm{Val}\right)$ are associated with a twofold in vivo (OR 2.17; 95\% CI 1.57-3.01; P <0.001) and a fourfold $e x$ vivo (OR 4.12; 95\% CI 1.90-9.29; $\mathrm{P}<0.001$ ) increase of parasite transmission from the human host to the Anopheles vector.

These findings represent the first demonstration that human genetic variation may also influence the transmission dynamics of an infectious disease. Interestingly, together with previous evidence on the protection against malaria conferred by $\mathrm{HbC}$ and $\mathrm{HbS}$, the assembly of the collected parasitological and entomological information suggests that single $\beta$ globin mutations may

${ }^{1}$ Institut de Recherche pour le Développement(IRD), Unité de Recherche 16, Montpellier, France

Full list of author information is available at the end of the article confer both a higher resistance to the disease for the host and higher transmissibility for the parasite.

\begin{abstract}
Author details
'Institut de Recherche pour le Développement(IRD), Unité de Recherche 16, Montpellier, France. ${ }^{2}$ Centre de Recherche et de Veille sur les maladies Emergentes dans I'Océan Indien (CRVOI), Sainte Clotilde La Réunion. 'Department of Public Health Sciences, University of Rome 'La Sapienza', Rome, Italy. ${ }^{4}$ Institut de Récherche en Sciences de la Santé (IRSS), Direction Régionale de Bobo-Dioulasso, Bobo Dioulasso, Burkina Faso. ${ }^{5}$ RDD, Unité de Recherche 016, Organisation de Coordination pour la lutte contre les Endémies en Afrique Centrale, Yaoundé, Cameroon.
\end{abstract}

Published: 20 October 2010

\section{Reference}

1. Gouagna LC, Bancone G, Yao F, Yameogo B, Dabiré KR, Costantini C, Simporé J, Ouedraogo JB, Modiano D: Genetic variation in human HBB is associated with Plasmodium falciparum transmission. Nat Genet 2010, 42:328-331.

doi:10.1186/1475-2875-9-S2-017

Cite this article as: Gouagna et al: Impact of protective haemoglobins C and $\mathrm{S}$ on $P$. falciparum malaria transmission in endemic area. Malaria Journal 2010 9(Suppl 2):017.

Submit your next manuscript to BioMed Central and take full advantage of:

- Convenient online submission

- Thorough peer review

- No space constraints or color figure charges

- Immediate publication on acceptance

- Inclusion in PubMed, CAS, Scopus and Google Scholar

- Research which is freely available for redistribution

Submit your manuscript at www.biomedcentral.com/submit 